\title{
The Relationship Between Digital Game Addiction and Social Tendencies of Secondary School Students
}

\author{
Mustafa Bas*, Serkan Kabak \\ Turkey \\ Study Area: Trabzon, Turkey \\ Coordinates: $41^{\circ} \mathrm{oo}^{\prime} 18^{\prime \prime} \mathrm{N} ; 39^{\circ} 43^{\prime} 21^{\prime \prime} \mathrm{E}$
}

Department of Sport Sciences, Trabzon University, Trabzon,

Keywords: Digital Game, Addiction, Social Tendency

\section{Introduction:}

It is an undeniable fact that developing technology provides many practices to human life and shapes many basic life activities from education to health, from transportation to communication and entertainment, and in addition, games, which are one of these basic life activities, also took their share from this change. Game behaviour, which started with human imitation of certain natural phenomena, has gained a different dimension today with imaginary games (digital games) played with special computer software and game tools. It is a known fact that this developing technology, together with the practices it brings to human life, has some negative consequences. One of the most important of these problems is technology addiction. Although technology addiction is an issue that is evaluated in a very wide range, one of the most prominent topics is computer addiction and the concept of "digital game addiction" evaluated under this heading (Hazar \& Hazar, 2017).

There is a lot of debate about whether digital games are beneficial or harmful for children. Some of the researchers argue that digital games improve hand-eye coordination, especially mental activities such as strategic thinking, problem-solving, and fast and correct decision-making, especially online games contribute to socialization and facilitate learning the use of technology. On the other hand, it is claimed that these games push individuals into a passive lifestyle, disconnect from social life, negatively affect family communication, and cause many negative physiological effects, especially on circulatory, respiratory, muscular and skeletal systems as a result of sitting still for hours due to the way they play, and in addition, especially violent games make individuals prone to violence and most

\section{Abstract}

The sample of the study consists of a total of 178 students ( 90 females and 88 males), who attend the 8th grade of secondary school. The personal information form, the Digital Game Addiction for Children Scale form and the social tendencies scale were used in the study. There was no statistically significant relationship between digital game addiction levels and social tendencies of secondary school students participating in the study. However, a low statistically significant positive correlation between digital game addiction and violence tendency, which is a subdimension of social tendencies was evidenced.

importantly, these games turn the players into game addicts (Smith, 2004; Gentila \& Anderson, 2006; Lieberman et al., 2009; Kars, 2010; Sahin \& Tugrul, 2012).

For the child, the game is the most important part of development. The child learns, matures and explores through play. The child playing game gets the opportunity to experience different roles, develop and reveal their imagination. "Game is an activity that starts from birth and continues throughout the life of a person, sometimes purposefully and sometimes without purpose" (Öncü \& Özbay, 2005). The child learns social rules, expresses his/her feelings and thoughts, discovers his/her abilities, and releases his/her accumulated energy through the game. According to Piaget, the game is a tool that enables the child to adapt to the world (Yavuzer, 2013). The child who plays the game has fun, relaxes, develops and gains skill. From this point of view, the game is an indispensable activity for every child.

Digital games have taken the place of the game that children and young people play with their friends in the park and garden. The digital game is divided into three as a video game, a console game or computer game. Games played in the computer environment are known "Computer Game", and games played by connecting to a TV or monitor such as Playstation, Xbox are known as 'Video Games'. "The definition commonly used in Turkey is "Computer Games". However, it is seen that the concept of digital games has also been used since the mid-20oos" (Binark \& Sütçü, 2008).

Digital game addiction, one of the behaviour-based addictions, is a situation that has consequences such as the individual's inability to stop playing games for a long time, associating the game with his/her real life, disrupting his/her responsibilities due to playing the game and 
preferring playing games to other activities. Today, digital games have become the most important commodity of daily consumer life globally. Groups of people of all ages devote a significant part of their daily lives to these games (Binark \& Sütçü, 2008).

As emphasized in Freud's theory of personality, human beings, by their nature, tend to run after the experiences they like and avoid negative experiences while repeating positive experiences (cited in Duyan et al., 2012). Selfcontrol, which can also be defined as the ability to control one's behaviour, is the ability to suppress or change the inner reactions, as well as to divide undesirable behavioural tendencies and avoid exhibiting them (Tangney et al., 2004).

One of the features that distinguish humans from other living things is that they are a social being. While the person is socializing, s/he starts to participate in some social activities. It begins to lead a common life with its compliance with the norms of social life such as eating, drinking, playing, sleeping, and obeying the traditions and customs of the society in which it lives. To the extent that $\mathrm{s} /$ he is aware of social life, $\mathrm{s} /$ he starts to participate in social activities such as sports and arts.

Although socialization takes a lifetime, the most important periods are thought to be childhood and adolescence (Bozyigit \& Madran, 2013). In this process, many factors such as school, family, mass media and environment play a role in socialization. The activities that the child participates in socializing environments affect situations such as academic achievement, physical, mental and psychosocial skills. Social orientations such as social cohesion, avoidance of substance and violence, family and school status, goals and ideals of the child affect their attitudes and habits in a positive or negative way.

In addition, when looking at the relevant research and statistics, it is seen that students spend most of their time on digital products such as computers, tablets, mobile phones and game consoles and have difficulty controlling the time spent with digital products. It is seen that in childhood, when real life is organic and the person is active, games that contain basic knowledge and skills give their places to the games that are virtual and played in a digital environment in a scenario where the person is passive, and which are mostly non-productive and does not provide any life skills and knowledge to the children. Digital game addiction is thought to be an area that needs to be emphasized and taken precautions, both in terms of children's lives and its impact on future generations. It is seen that the individual's ability to control himself/herself and engage in social activities are important in preventing digital game addiction. For this purpose, in this study, an answer to the question "Is there a significant relationship between the digital game addiction levels of students and their social tendencies?" was sought.

\section{Materials and Methods:}

Since this study aims to determine the relationship between the digital game addiction level of secondary school students and their social tendencies and to reveal how digital game addiction and social tendencies differ according to demographic characteristics, it is in a relational survey model.

Survey models were a descriptive approach to make a judgment about the whole population or the sample to be taken from the population in order to make a judgment about a situation that has existed or still exists. In the relational survey model, it was aimed to determine the presence and amount of interaction between multiple variables. Relational survey method was used to determine the relationships between variables and to predict possible results (Karasar, 1982/2017).

The sample of the study consists of a total of 178 students, 9o females and 88 males, who were in the 8th grade of secondary school, residing in the district centre of Akçaabat, Trabzon, in the fall semester of the academic year 2019-2020.

In this study, "Personal Information Form" for the purpose of the study, "Digital Game Addiction Scale" to measure digital game addiction levels and "Social Tendencies Scale" to measure social tendencies were used to collect data. In the personal information form determined by the researcher for the purpose of the research, there were three questions: gender, book reading habit and the habit of playing sports.

The "Digital Game Addiction for Children Scale" developed by Hazar \& Hazar (2017) and the social tendencies scale developed by Tekin et al., (2007) were used in the study."Digital Game Addiction for Children Scale" is a 5-point Likert-type scale with 24 questions. The lowest score that can be obtained from the scale is " 24 " and the highest score is "120". In the rating of the scale scoring, it is evaluated as "1-24: Normal group, 25-48: Low-risk group, 49-72: Risky group, 73-96: Dependent group, 97-120: Highly dependent group". The total reliability Croanbach Alpha internal consistency coefficient of the scale for this study was .94 and the Test-Retest correlation coefficient for the total scale was .84 .

The social tendencies scale developed by Tekin et al. (2007) is a 4-point Likert type with 26 questions. Social cohesion, substance avoidance, violence avoidance, family and school status, goals and ideal factors of the students were evaluated in the scale. The reliability Croanbach Alpha internal consistency coefficient of the social tendencies scale was .84.In the analysis of the data, negative items in the scales were reverse coded. The normality test of the data was examined. It was observed that the data did not show normal distribution. Statistical Mann Whitney U test was performed. 
variables didn't reveal any significant differences (Table-3).

\section{Discussion:}

It was concluded that the social tendencies, social cohesion, violence tendencies, substance avoidance tendencies, school status, family status, negative goals-ideals of the secondary school students participating in the study did not differ statistically significantly according to gender. Tekin et al. (2007) reported that the female students' scores of violence avoidance, goals and ideals were higher than male students and their school status was lower than male students. It can be said that the difference in the results of the research may be due to the sample groups and the change in social gender roles.

The digital game addiction levels of the participants differed significantly with respect to the gender variable. Digital game addiction levels of male participants were statistically significantly higher than female participants. This result is similar to the findings of Funk, 1993; Fisher, 1994; Griffiths \& Hunt, 1995; Griffiths \& Hunt, 1998; Kubey et al., 2001; Bonannoa \& Kommers, 2005; Onay et al., 2005; Horzum, 2011; Güllü et al., 2012. We can say that the reason for the similarity of these results is that the male participants have more opportunities to use the places that provide the opportunity to play games such as internet cafes. It was found that the social cohesion of the participants showed a statistically significant difference according to their book-reading habits. It was concluded that the social cohesion of secondary school students who read books was statistically significantly higher than that of secondary school students who do not read. Tekin et al. (2007) obtained similar results in the social tendencies scale development study. The reason for the high social cohesion of students who read books can be shown as the ability to reflect the information obtained from the books read into daily relationships.

The violence tendencies and negative goals-ideals of the participants differed statistically significantly according to their book-reading habits. It was concluded that the violent tendencies and negative goals-ideals of secondary school students who read books were statistically significantly lower than the violent tendencies and negative goals-ideals of secondary school students who do not read. Evcin, 2010; Anderson et al., 2010; Çakilci, 2013; Ergür, 2015 foundthat the violent tendencies of participants who play digital games increased. The habit of reading books is important in terms of directly contributing to the development of a healthy and strong personality, strengthening communication skills and mental development. For this reason, it is common for individuals who read books to have high goals and avoid violence.

The social tendencies, social cohesion, violent tendencies, substance avoidance tendencies, school status, family status, negative goals-ideals of the participants included in the study do not differ statistically according to their habits of playing sports. It is thought that the limited opportunities sports of the participants included in the study due to the insufficiency of the sports fields had an effect on the result.

The digital game addiction levels of the participants differed statistically significantly according to their habits of playing sports. The digital game addiction levels of secondary school students who do not play sports were statistically significantly higher than secondary school students who play sports. The study of Lee \& Kim (2015) shown that students' participation in sports activities helps reduce game addiction. On the other hand, Ekinci et al. (2016) found in their study on high school students that there was no relationship between doing sports regularly and game addiction. Conducting the study at the high school level may cause a difference in the results obtained. Considering the importance of the game for children, sports activities that will make the child feel good in physical, mental and social terms should be considered as the primary choice of children.

As a result, secondary school children should gain the habit of reading more books in order to socialize, have a good personality and at the same time be a beneficial individual to society. Reading books contributes to both the mental development and social development of the individual. The habit of playing sports provides the physical, motor, mental and social development of the individual. Therefore, children should gain the habit of both reading books and playing sports from an early age in order to raise a sensitive and beneficial generation. Digital game addiction should be kept under control as much as possible, as it negatively affects both habits.

\section{References:}

Anderson, C.A., Shibuya, A. \& Ihori, N. (2010): Violent Video Game Effects On Aggression, Empathy, And Prosocial Behavior In Eastern And Western Countries: A MetaAnalytic Review. Psychol. Bull., 136:151-173.

Binark, M. \& Sütçü, G. (2008): Dijital Oyun. Pub. by: Kalkedon, Istanbul.

Bonannoa, P. \& Kommers, P.A.M. (2005): Gender differences and styles in the use of digital games. Edu. Psychol., 25(1):13-14.

Bozyigit, S. \& Madran, C. (2013): Çocuklarin ÇevreBilinçli Tüketici Olarak Sosyallesmesinde Annelerin Çocuk Yetistirme Tutumlarinin Rolü (DoktoraTezi). Çukurova Üniversitesi Sosyal Bilimler Enstitüsü, Adana.

Çakilci, E. (2013): Çok Oyunculu Çevrimiçi Video Oyunu Oynayan Bireylerde Video Oyun Bagimliligi \& Saldirganlik (Yüksek Lisans Tezi). Baskent Üniversitesi, Sosyal Bilimler Enstitüsü, Ankara.

Duyan, V., Gülden, Ç. \& Gelbal, S. (2012): Öz-DenetimÖlçegi Ödö: Güvenirlik and GeçerlikÇalismasi. Toplum Sosyal Hizmet, 23(1):25-38.

Ekinci, N.E., Üstün, Ü.D. \& Özer, Ö. (2016): An investigation of the relationship between digital game addiction, gender and regular sport participation. J. Edu. Culture Soc. Içinde (s. 298- 
Results:

Table-1: Mann Whitney U test results for the digital game addiction and the sub-dimensions of social tendencies variable according to the gender variable

\begin{tabular}{lllllll}
\hline Variables & Gender & $N$ & \multicolumn{5}{l}{ Mean Rank Rank Sum U } & P \\
\hline Digital & Female & 90 & 57.23 & 4128 & 1411 & .000 \\
Game & Male & 88 & 99.76 & 7958 & & \\
Addiction & Total & 178 & & & & \\
Social & Female & 90 & 78.46 & 5734 & 3151 & .673 \\
Cohesion & Male & 88 & 79.02 & 6463 & & \\
& Total & 178 & & & & \\
Violence & Female & 90 & 73.85 & 5494.50 & 2826 & .175 \\
tendency & Male & 88 & 82.32 & 6980.40 & & \\
& Total & 178 & & & & \\
Substance & Female & 90 & 77.01 & 5608.52 & 2923 & .523 \\
Avoidance & Male & 88 & 80.78 & 6604.40 & & \\
& Total & 178 & & & & \\
School & Female & 90 & 77.81 & 5692.52 & 3105 & .687 \\
Status & Male & 88 & 79.12 & 6520.38 & & \\
& Total & 178 & & & & \\
Family & Female & 90 & 75.69 & 5643 & 2806 & .521 \\
Status & Male & 88 & 80.24 & 6715 & & \\
& Total & 178 & & & & \\
Negative & Female & 90 & 76.84 & 5611 & 2918 & .527 \\
Goals- & Male & 88 & 79.91 & 6683 & & \\
Ideals & Total & 178 & & & & \\
\end{tabular}

Table-2: Mann Whitney U test results for digital game addiction, social tendencies variable and sub-dimensions of social tendencies according to book reading habits

\begin{tabular}{|c|c|c|c|c|c|c|}
\hline Variables & $\begin{array}{l}\text { Book Read } \\
\text { Habit }\end{array}$ & $\mathrm{N}$ & $\begin{array}{l}\text { Mean } \\
\text { Rank }\end{array}$ & $\begin{array}{l}\text { Rank } \\
\text { Sum }\end{array}$ & $\mathrm{U}$ & $P$ \\
\hline $\begin{array}{l}\text { Digital } \\
\text { Game } \\
\text { Addiction }\end{array}$ & $\begin{array}{l}\text { I Read } \\
\text { I don't } \\
\text { Total }\end{array}$ & $\begin{array}{l}87 \\
91 \\
178\end{array}$ & $\begin{array}{l}70.89 \\
84.51\end{array}$ & $\begin{array}{l}5028 \\
7167\end{array}$ & 2491 & .054 \\
\hline $\begin{array}{l}\text { Social } \\
\text { Cohesion }\end{array}$ & $\begin{array}{l}\text { I Read } \\
\text { I don't } \\
\text { Total }\end{array}$ & $\begin{array}{l}87 \\
91 \\
178\end{array}$ & $\begin{array}{l}71.80 \\
83.76\end{array}$ & $\begin{array}{l}5217 \\
7036\end{array}$ & 2469 & .077 \\
\hline $\begin{array}{l}\text { Violence } \\
\text { tendency }\end{array}$ & $\begin{array}{l}\text { I Read } \\
\text { I don't } \\
\text { Total }\end{array}$ & $\begin{array}{l}87 \\
91 \\
178\end{array}$ & $\begin{array}{l}86.55 \\
70.45\end{array}$ & $\begin{array}{r}6176.45 \\
6049.27\end{array}$ & 2376.42 & .001 \\
\hline $\begin{array}{l}\text { Substance } \\
\text { Avoidance }\end{array}$ & $\begin{array}{l}\text { I Read } \\
\text { I don't } \\
\text { Total }\end{array}$ & $\begin{array}{l}87 \\
91 \\
178\end{array}$ & $\begin{array}{l}66.73 \\
86.55\end{array}$ & $\begin{array}{l}4874 \\
7396\end{array}$ & 2275 & .000 \\
\hline $\begin{array}{l}\text { School } \\
\text { Status }\end{array}$ & $\begin{array}{l}\text { I Read } \\
\text { I don't } \\
\text { Total }\end{array}$ & $\begin{array}{l}87 \\
91 \\
178\end{array}$ & $\begin{array}{l}73.90 \\
81.86\end{array}$ & $\begin{array}{l}5268 \\
6941\end{array}$ & 2632 & .178 \\
\hline $\begin{array}{l}\text { Family } \\
\text { Status }\end{array}$ & $\begin{array}{l}\text { I Read } \\
\text { I don't } \\
\text { Total }\end{array}$ & $\begin{array}{l}87 \\
91 \\
178\end{array}$ & $\begin{array}{l}77.81 \\
78.94\end{array}$ & $\begin{array}{l}5648.63 \\
6771.54\end{array}$ & 3019.40 & .863 \\
\hline $\begin{array}{l}\text { Negative } \\
\text { Goals- } \\
\text { Ideals }\end{array}$ & $\begin{array}{l}\text { I Read } \\
\text { I don't } \\
\text { Total }\end{array}$ & $\begin{array}{l}87 \\
91 \\
178\end{array}$ & $\begin{array}{l}78.43 \\
77.71\end{array}$ & $\begin{array}{l}5624 \\
6589\end{array}$ & 3083 & .890 \\
\hline $\begin{array}{l}\text { Digital } \\
\text { Game- } \\
\text { Addiction }\end{array}$ & $\begin{array}{l}\text { I Read } \\
\text { I don't } \\
\text { Total }\end{array}$ & $\begin{array}{l}87 \\
91 \\
178\end{array}$ & $\begin{array}{l}69.31 \\
87.02\end{array}$ & $\begin{array}{l}5001.30 \\
7301.43\end{array}$ & 2368.31 & .020 \\
\hline
\end{tabular}

The digital game addiction level of secondary school students shown a statistically significant difference according to gender. The digital game addiction levels of male secondary school students were statistically significantly higher than female secondary school students. Rest parameters did not differ statistically with respect to gender (Table-1).

The social cohesion of secondary school students shown a statistically significant difference as per their bookreading habits. It was seen that the social cohesion of secondary school students who read books was statistically significantly higher than that of secondary school students who do not read. The violence tendencies of secondary school students shown a statistically significant difference according to their book-reading habits. It was seen that the negative goals-ideals of secondary school students differ statistically significantly according to their book-reading habits. The negative goals-ideals of secondary school students who read books were statistically significantly lower than that of secondary school students who do not read. Rest parameters did not differ statistically with respect to gender (Table-2).

Table-3: Mann Whitney U test results for the digital game addiction and the sub-dimensions of social tendencies variable according to the habit of playing sports

\begin{tabular}{|c|c|c|c|c|c|c|}
\hline Variables & $\begin{array}{l}\text { Playing } \\
\text { Habit }\end{array}$ & $\mathrm{N}$ & Mean Rank & Rank Sum & $\bar{U}$ & $\mathrm{P}$ \\
\hline $\begin{array}{l}\text { Digital } \\
\text { Game } \\
\text { Addiction }\end{array}$ & $\begin{array}{l}\text { I Play } \\
\text { I Don't } \\
\text { Total }\end{array}$ & $\begin{array}{l}118 \\
60 \\
178\end{array}$ & $\begin{array}{l}72.86 \\
88.97\end{array}$ & $\begin{array}{l}7663 \\
4589\end{array}$ & 2183 & .021 \\
\hline $\begin{array}{l}\text { Social } \\
\text { Cohesion }\end{array}$ & $\begin{array}{l}\text { I Play } \\
\text { I Don't } \\
\text { Total }\end{array}$ & $\begin{array}{l}118 \\
60 \\
178\end{array}$ & $\begin{array}{l}80.21 \\
74.93\end{array}$ & $\begin{array}{l}8390 \\
3869\end{array}$ & 2577 & .354 \\
\hline $\begin{array}{l}\text { Violence } \\
\text { tendency }\end{array}$ & $\begin{array}{l}\text { I Play } \\
\text { I Don't P } \\
\text { Total }\end{array}$ & $\begin{array}{l}118 \\
\text { lay } \\
178\end{array}$ & $\begin{array}{l}74.89 \\
60\end{array}$ & $\begin{array}{l}7917 \\
84.96\end{array}$ & $\begin{array}{l}2378 \\
4396\end{array}$ & .189 \\
\hline $\begin{array}{l}\text { Substance } \\
\text { Avoidance }\end{array}$ & $\begin{array}{l}\text { I Play } \\
\text { I Don't } \\
\text { Total }\end{array}$ & $\begin{array}{l}118 \\
60 \\
178\end{array}$ & $\begin{array}{l}77 \cdot 36 \\
81.43\end{array}$ & $\begin{array}{l}8094 \\
4163\end{array}$ & 2598 & .490 \\
\hline $\begin{array}{l}\text { School } \\
\text { Status }\end{array}$ & $\begin{array}{l}\text { I Play } \\
\text { I Don't } \\
\text { Total }\end{array}$ & $\begin{array}{l}118 \\
60 \\
178\end{array}$ & $\begin{array}{l}82.71 \\
70.65\end{array}$ & $\begin{array}{l}8684 \\
3573\end{array}$ & 2293 & .076 \\
\hline $\begin{array}{l}\text { Family } \\
\text { Status }\end{array}$ & $\begin{array}{l}\text { I Play } \\
\text { I Don't } \\
\text { Total }\end{array}$ & $\begin{array}{l}118 \\
60 \\
178\end{array}$ & $\begin{array}{l}83.64 \\
69.465\end{array}$ & $\begin{array}{l}8667 \\
3558\end{array}$ & 2281 & .062 \\
\hline $\begin{array}{l}\text { Negative } \\
\text { Goals- } \\
\text { Ideals }\end{array}$ & $\begin{array}{l}\text { I Play } \\
\text { I Don't P } \\
\text { Total }\end{array}$ & $\begin{array}{l}118 \\
\text { lay } \\
178\end{array}$ & $\begin{array}{l}74 \cdot 96 \\
60\end{array}$ & $\begin{array}{l}7879 \cdot 40 \\
84.70\end{array}$ & $\begin{array}{l}2294.40 \\
4363.40\end{array}$ & .182 \\
\hline
\end{tabular}

The digital game addiction levels of secondary school students shown a statistically significant difference according to their habit of playing sports. The digital game addiction levels of secondary school students who do not play sports were statistically significantly higher than secondary school students who play sports. Rest of the 


\section{ORIGINAL ARTICLE}

303).

Ergür, G. (2015): SiddetIçerikli Bilgisayar Oyunu OynayanIkinci Kademe Ögrencilerinin Saldirganlik Egilimlerinin and Benlik Saygi DüzeylerininIncelenmesi (Yüksek Lisans Tezi). Istanbul Arel Üniversitesi, Sosyal Bilimler Enstitüsü, Istanbul.

Evcin, S. (2010): Bilgisayar Oyunlarinin Ilkögretim Ikinci Kademe Ögrencilerinin Saldirganlik Egilimine EtkisininIncelenmesi (Yüksek Lisans Tezi). Maltepe Üniversitesi, Sosyal Bilimler Enstitüsü, Istanbul.

Fisher, S. (1994): Identifying Video Game Addiction In Children And Adolescents. Addict. Behav., 19:545-553.

Funk, J.B. (1993): Reevaluating the impact of Violent Video Games. Clin. Pediatr., 32(2):86-90.

Gentile, D.A. \& Anderson, C.A. (2006): Video games. Encyclop. Human Develop., 3(8):1303-1307.

Griffiths, M.D. \& Hunt, N. (1995): Computer Game Playing In Adolescence: Prevalence And Demographic Indicators. J. Comm. Appl. Soc. Psychol., 5:189-193.

Griffiths, M.D. \& Hunt, N. (1998): Dependence on computer games by adolescents. Psychol. Rep., 82(2):475-480.

Güllü, M., Arslan, C., Dündar, A. \& Murathan, F. (2012): Ilkögretim Ögrencilerinin Bilgisayar Oyun Bagimlilik larininInce lenmesi. Adiyaman Üniversitesi Sosyal Bilimler Enstitüsü Dergisi, 9:89-100.

Hazar, Z. \& Hazar, M. (2017): Çocuklar Için Dijital Oyun Bagimliligi Ölçegi.J.Human Sci., 14(1):203-216.

Horzum, M. (2011): Ilkögretim Ögrencilerinin Bilgisayar Oyunu Bagimlilik Düzeylerinin Çesitli Degiskenlere Göre Incelenmesi. Egitim \& Bilim, S.36.

Karasar, N. (2017): Bilimsel Arastirma Yöntemi (32. Baski). Pub. by: Nobel, Ankara.
Ambient Science, 2020: Vol. 07(Sp1); 189-193 DOI:10.21276/ambi.2020.07.sp1.oa25

Kars, G.B. (2010): Siddetiçerik libilgisayaroyun larininçocuk lardasa ldirganligaetkisi. Yüksek Lisans Tezi, Ankara Üniversitesi Saglik Bilimleri Enstitüsü, Ankara.

Kubey, R.W. Lavin, M.J. \& Barrows, J.R. (2001): Internet use and collegiate academic performance decrements: early findings. J. Commun., 52(2):366-382.

Lee, C. \& Kim, O. (2015): Predictors of online game addiction among Korean adolescents. Addic. Res. Theory, 25(1):58-66.

Lieberman, D.A., Fisk, M.C. \& Biely, E. (2009): Digital games for young children ages three to six: from research to design. Comp. Schools, 26 (3):299-313.

Onay, P.D, Tüfekçi, A. \& Çagiltay, K. (2005): Türkiye'deki Ögrencilerin Bilgisayar Oyunu Oynama Aliskanliklari \& OyunTercihleri: ODTÜ \& Gazi Üniversitesi Ögrencileri Arasi Karsi lastirmali Bir Çalisma, Bilisim Teknolojileri Isiginda Egitim Konferansi, Ankara.

Öncü, E. \& Özbay, E. (2005): Okul Öncesi ÇocuklarIçin Oyun. Pub. by: Kök, Ankara.

Smith, G. (2004): How do computer games affect your children?. Eurasian J. Edu. Res., 17(9):72-80.

Sahin, C. \& Tugrul, M. (2012): Ilkögretimögrenci lerininbi lgisayaroyunubagim lilikdüzey lerininincelenmesi. Zeitschrift für die Welt der Türken, 4(3):15-30.

Tangney, J.P., Boone A.L. \& Baumeister, R.F. (2004). High SelfControl Predicts Good Adjustment, Less Pathology, Better Grades, and Interpersonal Success. Pub. by: Wiley Online Library.

Tekin, O., Özkara, A., Cebeci, S., Isik, B., Çatal, F., Dogan, D. G., Bilici, M. \& Kara, S. (2007): Sosyal Egilimler Ölçegi. Yeni Tip Dergisi, 24:198-204.

Yavuzer, H. (2013): ÇocukPsikolojisi (36. Baski). Pub. by: Remzi, Istanbul. 